\title{
Final targets for developing Russian insurance market within a megaregion
}

\author{
Irina Viktorovna Grigorenko \\ Volgograd State University \\ Institute of Economics and Finance \\ Volgograd, Russia \\ grigorenkoiv@volsu.ru
}

\author{
Ellada Alexandrovna Tikhonovich \\ Volgograd State University \\ Institute of Economics and Finance \\ Volgograd, Russia \\ tihonovichea@volsu.ru
}

\begin{abstract}
The paper explores the trends for developing the insurance market in Russia within megaregional economic space. It reveals major problems of building the single insurance market in the EEU megaregion, specifying the considerable difference both in levels of the social and economic development and insurance legislation of the member-nations. The paper outlines the tasks which seek to be implemented for the purpose of building the single insurance market: harmonizing legislation of the parties, which would regulate the insurance activities, constructing the common system of insurance coverage as well as adjusting the insurance legislation of the parties to the requirements of international standards and practices of insurance control . The current research has enabled to identify the final targets of the Russian insurance market under conditions of international integration and reveal the competitive edge of insurance companies which is provided through consistent implementation of these requirements.
\end{abstract}

Keywords - megaregion, insurance market, financial sustainability, Solvency II, international economic integration, EEC.

\section{INTRODUCTION}

Development of global and regional economy occurs under ongoing integration processes which cover all aspects of economic activity and are the prerequisites for creating the single conditions for business activities and identical legislative basis in megaregional partnerships.

This idea is in line with E.I. Inshakova's view, who believes that "exploring the processes of forming and developing megaregions is of particular significance in the context of ensuring national competitiveness at various levels global economic system" [1].

According to A.Y. Voloshina, megaregions arise "within the space of contiguous countries' border macroregions involved in intensive economic interaction and jointly performing global functions in the course of its implementation" [2]. Megaregional economic space unites national macrospaces, possessing specific qualitative characteristics; it takes its shape and develops in response to conditions, resources and factors of global and national character. International regional (megaregional) integration associations can serve as an example of the megaregion under consideration.

The economic space of such megaregions "perpetuates extensively and evolves from isolated national economic spaces to common, subsequently single integrated one, characterized by a high degree of homogeneity and continuity" [3].

These tendencies have been reflected in the Eurasian Economic Union (EEU), which, we believe, complies with the criteria of a megaregion, being a group of contiguous countries in the global economy, bound with joint implementation of global functions.

The circle of financial market participants whose activities are affected by integration processes is sufficiently wide, and arising changes manifest themselves in all its segments, including the insurance market. As for the research into international economic integration of insurance services, N.G. Mandra notes that "flows of capital under financial integration stimulate building of the insurance market which is to ensure the coverage international social and economic risks" [4].

National insurance markets of the megaregion in question adjust themselves to the single regime of trading insurance services develops according to levels of economic development in member-nations and national and regional strategies for economic development. Being interested in economic convergence, nations of the community have developed the conception of split-level integration enabling them to singly determine, which directions of integration development or separate integration projects to participate in and to what extent.

However, taking into account the ever-increasing competition factor, one should determine the final targets of the national insurance market under the current international integration. It requires singling out major problems of building the single insurance market within the EEU as well as specifying the tasks of finalizing the process of shaping the common financial market.

\section{MATERIALS AND METHODS (MODEL)}

The purpose of the research has been achieved through applying the methodology of systemic approach to the analysis of regional financial markets of the EEU member- 
states, uncovering industrial peculiarities of their insurance markets.

The research synthesizes structural (in terms of analyzing major indices of insurance markets in the megaregion's member-states) and comparative (in terms of comparing the levels of their social and economic development and major indices of national insurance markets development) analyses.

Expert assessment of international insurance jurisdictions and current state of the Russian insurance market have enabled to draw some conclusion concerning the final targets of the Russian insurance market under ongoing international integration.

\section{RESULTS AND DISCUSSION}

In 2009 the Protocol on establishing the common insurance market was signed whose statutes specify the principal directions of activities in the Eurasian Economic Union member-states (Republics of Armenia, Balarus, Kazakhstan, Kyrgystan and the Russian Federation) and tasks to be implemented for the purpose of establishing the common insurance market, including [5]:

- harmonizing the legislation of the signatories to regulate the insurance activities;

- building the common system of insurance coverage of investors' rights and interests in the Eurasian Economic Union member-states;

- coordinating the insurance legislation of the signatories in accordance with requirements of international standards and practices of insurance control.

It is worth mentioning that, it was not until January 1, 2015 when the Treaty on the Eurasian Economic Union came into effect (legal wording of August 12, 2017), according to which " by 2025 the insurance markets of the Treaty memberstates are to be integrated, which calls for harmonizing the insurance legislation" [6]. It is no coincidence that such a long timeline has been set: financial markets are complex, varied, susceptible to regulating impact, and their control, particularly supranational one within the megaregion, is to be exercised taking into account the experiences of all the member-states. Thus, the analysis of problems associated with establishing the single insurance market will contribute to developing the comprehensive set of measures to prepare for entering the EEU common insurance space.

However, the process of establishing the single insurance market within this community has a number of complexities due to the substantial difference in the levels of social and economic development of the member-states.

Fig. 1 shows the comparative analysis [7] ratios of the gross domestic product (GDP) per capita in EEU nations in relation to Russia, taking into account that GDP per capita in Russia is taken as a unit. As you can see, in terms of this index Russia is followed by Kazakhstan and Belarus, while Armenia and Kyrgyzstan considerably lag behind in terms of GDP per capita ratios.

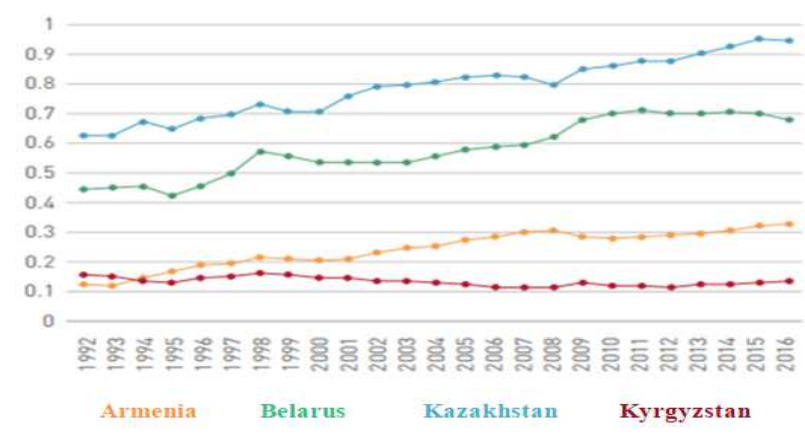

Fig. 1 - GDP per capita ratios in terms of purchasing-power parity in the EEU nations in relation to Russia, index

According to Eurasian Economic Commission (Table 1) [8] GDP indices showed positive dynamics up to 2015 in all member-states. Since 2015, however, this index has decreased sharply. Still, having analyzed each nation's share in the aggregate GDP one should note that the share of Armenia has increased from $0,43 \%$ in 2012 to $0,71 \%$ in 2016 , of Kyrgyzstan - from $0,27 \%$ to $0,44 \%$. The rest of nations' indices changed positively up to 2015 , followed by a moderate decline: Belarus in 2016 - slightly over $3 \%$, Kazakhstan $\approx 9 \%$, Russia $\approx 87 \%$.

Table 1 - Dynamics of GDP indices in the EEU nations (in current prices; US billion dollars)

\begin{tabular}{|c|c|c|c|c|c|}
\hline Nations & 2012 & 2013 & 2014 & 2015 & 2016 \\
\hline Armenia & 10619 & 11121 & 11610 & 10529 & 10547 \\
\hline Belarus & 65428 & 74761 & 78536 & 55317 & 47165 \\
\hline Kazakhstan & 208002 & 236633 & 221418 & 184387 & 135005 \\
\hline Kyrgyzstan & 6606 & 7335 & 7469 & 6678 & 6552 \\
\hline Russia & 2154067 & 2231827 & 2085848 & 1372117 & 1286153 \\
\hline EEU & $\mathbf{2 4 4 4 7 2 2}$ & $\mathbf{2 5 6 1 6 7 7}$ & $\mathbf{2 4 0 4 8 8 1}$ & $\mathbf{1 6 2 9 0 2 8}$ & $\mathbf{1 4 8 5 4 2 2}$ \\
\hline
\end{tabular}

As a result of the comparative analysis of insurance jurisdictions undertaken we have found major differences and common approaches to establishing insurance systems regulation provisions in the member-nations. The analysis has also revealed the considerable difference in major indices of national insurance markets development in these nations: in the number of insurance companies, their asset scales, as well as in gross indices of insurance premium collection, insurance benefits and insurance contracts. Table 2 [8] shows the dynamics of major insurance indices in the EEU nations which has demonstrated that Kazakhstan is closest to Russia in terms of its insurance market size.

In 2016 the EEU member-states had 337 operating insurance companies, 256 of them are in Russia, 32 in Kazakhstan, 23 in Belarus, 19 in Kyrgyzstan, 7 in Armenia. It is obvious that the Russian insurance market size exceeds the one of any other EEU member-nation. For instance, "the number of concluded insurance contracts in Russia is approximately 7 times higher than in all the other EEU nations, with the volumes of insurance contributions $\approx 10$ times higher, the value of insurance benefits paid - over 14 times, the value of insurance reserves formed by Russian insurance 
companies 8 times exceeding ones in all the other membernations" [9].

Table 2 - Indices of the state of insurance markets in the EEU nations as of 01.01.2017.

\begin{tabular}{|c|c|c|c|c|c|}
\hline Nations & 2012 & 2013 & 2014 & 2015 & 2016 \\
\hline \multicolumn{7}{|c|}{ Amount of insurance premiums } \\
\hline Armenia & 88 & 87 & 72 & 66 & 69 \\
\hline Belarus & 518 & 741 & 708 & 506 & 486 \\
\hline Kazakhstan & 1420 & 1664 & 1319 & 1187 & 1043 \\
\hline Kyrgyzstan & 18 & 20 & 19 & 13 & Н.Д. \\
\hline Russia & 26150 & 28513 & 26024 & 16940 & 13240 \\
\hline \multicolumn{7}{|c|}{ Amount of insurance benefits } \\
\hline Armenia & 36 & 48 & 53 & 28 & 30 \\
\hline Belarus & 247 & 308 & 320 & 291 & 269 \\
\hline Kazakhstan & 457 & 342 & 348 & 303 & 242 \\
\hline Kyrgyzstan & 1 & 2 & 3 & 1 & Н.Д. \\
\hline Russia & 11934 & 12852 & 12474 & 8434 & 5433 \\
\hline
\end{tabular}

In Armenia, Russia and Belarus almost half of the insurance contributions is distributed for providing insurance benefits by underwriters. In Kazakhstan the proportion of insurance benefits is about $1 / 4$, in Kyrgyzstan - less than $10 \%$ (while in developed nations the value of this index reaches 70-80\%).

The value of the index enabling us to compare the levels of insurance development in certain countries is the ratio of insurance premiums and GDP which ranges between 7 and 10 $\%$ in the countries with developed insurance markets, while in the EEU member-states this ratio is considerably lower. The proportion of insurance contributions to GDP by the Russian Federation alone exceeds $1 \%$, in Belarus, Kazakhstan and Armenia it accounts for $0,6-0,9 \%$, with a highly insignificant difference among them, in Kyrgyzstana - as low as 0,2 \%.

Having conducted the analysis of the gross added value of financial and insurance activities from the perspective of economic activities type (Table.3), one should note that the greatest decline has taken place in Kyrgyzstan.

Table 3 - Dynamics of indices for gross added value of financial and insurance activities in the EEU member-states (in current prices; US billion dollars)

\begin{tabular}{|c|c|c|c|c|c|}
\hline Nations & 2012 & 2013 & 2014 & 2015 & 2016 \\
\hline Armenia & 424 & 446 & 497 & 405 & 428 \\
\hline Belarus & 2210 & 2212 & 2537 & 2089 & 1837 \\
\hline Kazakhstan & 4395 & 6485 & 6694 & 6452 & 4872 \\
\hline Kyrgyzstan & 242 & 277 & 291 & 240 & 33 \\
\hline Russia & 77517 & 89353 & 82909 & 48146 & 51648 \\
\hline EEU & 84354 & 98327 & 92451 & 56940 & 58662 \\
\hline
\end{tabular}

Thus, the study found that the difference in the requirements for insurance market subjects' activities in these countries result from dissimilar macroeconomic and industrial conditions.

It is worthwhile mentioning that the institutional development of national insurance systems of the membernations also varies.

In Russia (Bank of Russia), Kazakhstan (National Bank of Republic of Kazakhstan), Armenia (Central Bank of Armenia) the system of insurance regulation is consolidated in the megaregulator, in Kyrgyzstan National Service for Regulation and Control of financial markets under the Government of Kyrgyzstan acts a s a regulator, in Belarus the Finance Ministry performs the same functions. Kazakhstan and Belarus are still not among the WTO member-nations. Different approaches to determining the share of foreign involvement in the capital of insurance organizations are exercised. Significant variation in the countries of the megaregion under consideration is observed in the regulatory requirements for the minimum amount of authorized capital of insurance organizations, which directly affects the level of business solvency in an insurance company.

It should be emphasized that, in our view, the task of adjusting the Russian insurance legislation to the requirements of international standards of business solvency in insurance companies as well as international practices of insurance control for financial solvency is of greater importance.

Solving the problems of correlation between principles and requirements for business solvency of European and Russian insurance markets is particularly urgent in the context of international economic integration, since "implementing similar directives of assessing business solvency of insurance companies implies a close link between domestic and European insurance markets" [10].

Studying international insurance jurisdictions, we have found that "in 2002 directives 2002/12/EU and 2002/13/EU (under the umbrella name «Solvency $\mathrm{I} »$ ) reformed former methodologies of regulating business solvency of insurance companies, laying the foundations for a new assessment system. Following the introduction of Solvency I the European Commission initiated its work on the second generation of Solvency II directive enabling to assess risks of insurance activities, and its purpose is to improve control for insurance companies" [11]. Fig. 2 shows the major differences in the systems.

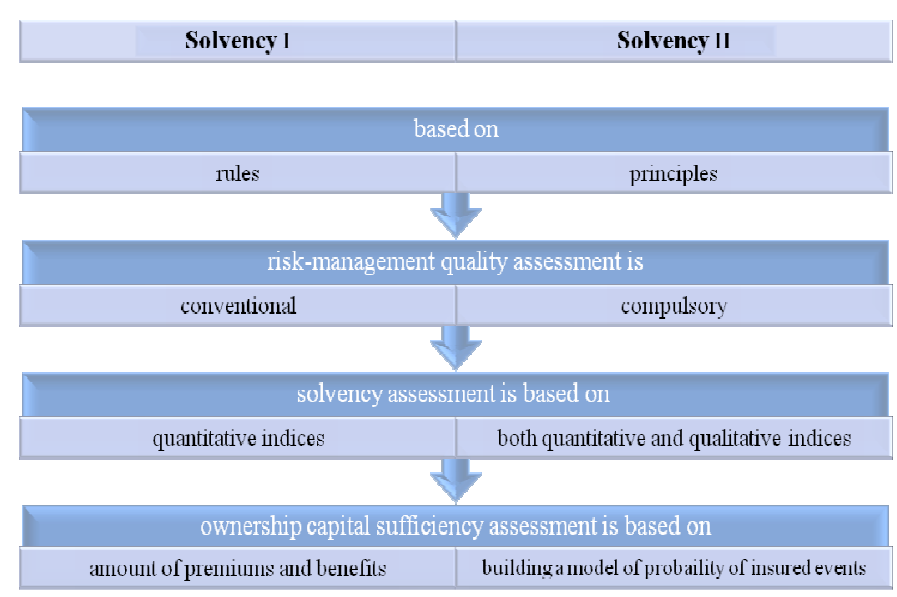

Fig. 2 - Major differences between Solvency I and Solvency II.

Russia's joining the WTO has activated the process of liberalizing the insurance market and revealed a major problem of Russian underwriters - undercapitalization. To 
enhance competitiveness of Russian insurance companies the legislative body has made changes to the requirements of increasing the amount of minimal authorized capital of underwriters.

Active preparation for transition to new industrial standards (for Russian underwriters as well) started in 2015. It presupposes that Central Bank carries out a policy of convergence of accounting systems and reporting in accordance with Russian accounting standards and international financial reporting standards. A number of regulatory documents were adopted, which since January 1, 2017 bound insurance companies to draw up and submit reports, equivalent to international standards of financial reporting, to regulatory authorities.

According to the estimates of Bank of Russia, full implementation of Solvency II system in the Russian insurance market can be done in 2019 at the earliest, taking into consideration all the necessary regulatory measures. The top priority of the megaregulator is to create essential prerequisites for willingness of market participants to accept new high standards. For this reason the possible transition by the targeted year appears to be an optimistic rather than a feasible scenario.

Solvency II model implementation in Russia as a way to ensure the integration of the domestic insurance market into the global one, requires a number preliminary measures and stringent market regulation.

However, there exist some obstacles in an attempt to make integration transitions. The current level of insurance regulation is still low: the existing requirements for capital (currently not reaching the level of European insurance companies) does not take into account the risks and structures of insurance and investment portfolios of an insurance company.

Table 4 [12] presents the comparative analysis of requirements for minimal amount of insurance companies' authorized capital in the countries of the megaregion in question.

Table 4 - Minimal amount of insurance companies' authorized capital in the EEU member-states.

\begin{tabular}{|c|c|c|c|}
\hline Country & Life insurance & $\begin{array}{c}\text { Insurance other } \\
\text { than life }\end{array}$ & Reinsurance \\
\hline Russia & $\begin{array}{l}240 \text { million } \\
\text { roubles }\end{array}$ & $\begin{array}{l}120 \text { million } \\
\text { roubles }\end{array}$ & $\begin{array}{l}480 \text { million } \\
\text { roubles }\end{array}$ \\
\hline Armenia & $\begin{array}{c}1,5 \text { bn drams } \\
\text { (180 million } \\
\text { roubles) }\end{array}$ & $\begin{array}{c}1,5 \text { bn drams } \\
\text { (180 million } \\
\text { roubles) }\end{array}$ & $\begin{array}{c}1,5 \text { bn drams } \\
\text { (180 million } \\
\text { roubles) }\end{array}$ \\
\hline Belarus & $\begin{array}{l}€ 5 \text { million } \\
\text { (312 million } \\
\text { roubles) }\end{array}$ & $\begin{array}{l}€ 5 \text { million } \\
\text { (312 million } \\
\text { roubles) }\end{array}$ & $\begin{array}{l}€ 5 \text { million } \\
\text { (312 million } \\
\text { roubles) }\end{array}$ \\
\hline Kazakhstan & $\begin{array}{l}1,1 \text { bn tenge } \\
\text { (330 million } \\
\text { roubles) }\end{array}$ & $\begin{array}{l}1,2 \text { bn tenge } \\
\text { ( } 360 \text { million } \\
\text { roubles })\end{array}$ & $\begin{array}{c}1,0 \text { bn tenge } \\
\text { (300 million } \\
\text { roubles) }\end{array}$ \\
\hline Kyrgyzstan & $\begin{array}{l}30 \text { million soms } \\
(27 \text { million } \\
\text { roubles })\end{array}$ & $\begin{array}{l}\text { 30-50 million } \\
\text { soms ( } 27-45 \\
\text { million roubles) }\end{array}$ & $\begin{array}{l}200 \text { million soms } \\
(180 \text { million } \\
\text { roubles })\end{array}$ \\
\hline
\end{tabular}

Organizing the risk management system also requires some improvements. Some companies apply certain components of risk management, but there is no systematic approach to this problem.

Exercising insurance control within new Solvency II directive can have positive effects on the domestic insurance market with regard to improving competition, restricting dumping and enhancing companies' reliability.

It should be noted that in the course of the present research into the EEU legislative basis we have found major discrepancies in the basic conditions of insurance activity, such as requirements for the licensing procedure, classification of industries, establishing authorized capital and other financial and economic indices, conditions for transfer of risks to reinsurance, etc.

Having identified the weaknesses and peculiarities of the insurance market in each of the EEU member-states, we revealed major problems of establishing the single insurance market within the megaregion: considerable differences in the insurance legislation of the member-states, low efficiency of insurance activity state regulation, lack of transparency in financial reporting, dissimilar conditions for access of foreign underwriters to the single economic space, etc.

The main assumption is that the conception of harmonizing the insurance systems regulation within the megaregion will be aimed at solving the following problems:

- systematizing work on drafting international agreements that are part of the mega-region legal framework and regulate the insurance market;

- determining conditions, terms, mechanisms and tools for establishing the common insurance market;

- organizing non-discriminatory mutual access to national insurance markets of the megaregions member-states;

- creating and developing infrastructure of the common insurance market;

- providing the common legal framework of the megaregion, including the introduction of the common terminology;

- transition to a single licensing of insurance companies in the megaregion;

- introducing a common approach to organizing compulsory insurance;

- convergence of standards for ensuring transparency and risk management of insurance organizations;

- establishing unified requirements for the subjects of the insurance market, including in the system of control over the solvency and financial stability of insurance companies;

- unifying the principles of supervision and control of insurance activities, strengthening the interaction of national insurance supervision bodies and introducing a single mega-regional supranational insurance supervision. 
The effectiveness of the combined financial markets is of immediate importance for insurance companies as financial indices of the companies are directly dependent on the efficient interaction of all elements of the financial market.

It should be specified that "the EEU member-states have agreed to follow the best global practices and Fundamental principles of insurance supervision adopted by the International Association of Insurance Supervisors (IAIS) while developing the insurance legislation" [13].

We have specified (Table 5) some requirements for improving the Russian insurance market, which should be focused on in the framework of international integration, and pointed out to the advantages for companies which are provided through agreed-upon meeting of the requirements, including international standards of financial reporting in the field of insurance and Solvency II.

Table. 5 - Final targets of the Russian insurance market under international integration

\begin{tabular}{|c|c|}
\hline Final targets & Advantages \\
\hline $\begin{array}{l}\text { unifying companies' industrial } \\
\text { standards; } \\
\text { uniform reporting formats (with } \\
\text { international standards of financial } \\
\text { reporting as a basis); } \\
\text { single approach to format, methods } \\
\text { of processing and analysis of } \\
\text { incoming reports; } \\
\text { automated reporting and control; } \\
\text { risk management and information } \\
\text { disclosure. }\end{array}$ & $\begin{array}{l}\text { Lack or low necessity for reviewing } \\
\text { system processes and databases; } \\
\text { efficient work of structural divisions } \\
\text { of insurance companies, as well as } \\
\text { reducing costs for ensuring their } \\
\text { activities; } \\
\text { willingness and improved } \\
\text { adaptability to fhanging } \\
\text { requirements in the field of } \\
\text { insurance; } \\
\text { reducing costs for processes of } \\
\text { modeling and data management, as a } \\
\text { result, improved relations with } \\
\text { investors. }\end{array}$ \\
\hline
\end{tabular}

\section{CONCLUSION}

Thus, the analysis of current trends in insurance activity development has enabled us to conclude that insurance industries in Russia and the European Union are undergoing dramatic structural changes. On the one hand, introducing Solvency II model of insurance companies' solvency assessment within the European Union will ensure the transition of the market to a new level of organizing insurance activities, improving financial stability of companies as well as the degree of financial security of their counteragents.

On the other hand, there is a need for harmonizing institutional provision in the EEU member-states which is intended to solve the problems revealed:

- various macroeconomic and industrial conditions;

- considerable differences in the insurance legislation;

- diverse institutional development of national insurance systems, e.g. low efficiency of insurance activities government regulation;

- dissimilar conditions for access of foreign underwriters to the single economic space;
- serious divergences in the basic conditions of insurance activities.

In our view, solving the problems mentioned above should be carried out stepwise, starting from establishing a single platform of entrance barriers to insurance markets.

It is reasonable to bring overarching norms and rules to the level of supranational regulation, including licensing, incorporating, investing, solvency supervising, dissolving (bankruptcy), managers' qualifications, interacting with authorized bodies. More specifically, it involves introducing the common terminology apparatus, specifying uniform requirements for subjects of the insurance market, such as harmonizing of licensing conditions, requirements for authorized (ownership) capital, accounting management, auditing, financial regulation. It also presupposes insurance companies' solvency control, as well as introduction of common approaches to managing compulsory types of insurance related to cross-border operations. We emphasize that solving these problems has to be supervised by a single megaregional authority of supranational insurance control.

It is worthwhile noting that "negotiations on integration of insurance markets of the CIS nations have been held for over a decade, but some breakthrough was slated not until the establishment of the EEU on the basis of the aforementioned treaty. In the late 2014 the Advisory Committee on Financial Markets under the Eurasian Economic Commission (EEC) has drawn up "Memorandum on cooperation among the Advisory Committee, Belarus Association of Insurers, Kazakhstan Association of Insurers and All-Russian Union of Insurers" [14]. This Memorandum is the basis for integration cooperation of professional insurance communities.

The Russian insurance market, despite the existing problems, is relatively developed, and serves as a starting point for generating programs of the single insurance market development in the EEU megaregion.

Russia's aspiration for adjusting the insurance legislation to international standards and practices of insurance control has triggered initiating some reforms of the insurance industry. Toughening requirements is a prerequisite for future reforming of the current system of assessing solvency and financial stability of national insurance companies, adjustment to Solvency II standards and integration of yet immature Russian insurance industry into the global financial market.

\section{Acknowledgment}

We express our gratitude to Institute of Economics and Finance of Volgograd State University and personally its Director, Doctor of Economics, Professor E.G. Russkova.

\section{References}


[1] E.I. Inshakova, "Megaregions: theory and practice of identification in the megaeconomic space" [Megaregiony: teoriya i praktika identifikatsii v prostranstve megaekonomiki] ,in Regional economy, South of Russia [Regional'naya ekonomika. Yug Rossii], Vol. 2, Eds. E.I. Inshakova, A.Y. Voloshina, 2013, pp. 14-19.

[2] Voloshina A.Yu., "Formation of mega-regions as a vector of regional development under globalization" [Obrazovanie megaregionov kak vektor regional'nogo razvitiya v usloviyakh globalizatsii] in Priorities of Russia [Prioritety Rossii], Eds. Voloshina A.Yu. Vol. 12 (69), 2010, p. 39.

[3] Inshakova, E.I., "Functions of mega-regions and mega-cities in the global economic system" [Funktsii megaregionov i megagorodov $\mathrm{v}$ global'noi ekonomicheskoi sisteme], in Bulletin of Volgograd State University [Vestnik Volgogradskogo gosudarstvennogo universiteta]. Series 3: The Economy. Ecology, Eds. Inshakova E.I.,.Vo loshina A.Yu, Vol.1, 2010, pp. 159-166.

[4] Mandra, N.G.,'International economic integration of insurance services: genesis, development trends" [Mezhdunarodnaya ekonomicheskaya integratsiya strakhovykh uslug: genezis, tendentsii razvitiya], in Economics, management, law: realities and perspectives. Collection of scientific articles, Eds. Drobyazko S.I., 2016., pp. 290-292.

[5] Federal Law of 05.05.2014 \# 89-FL "On ratification of the Protocol on the establishment of a common insurance market for the the Eurasian Economic Union member-states. URL: http://www.consultant.ru/law/hotdocs/33559.html/

[6] Treaty on the Eurasian Economic Union (Signed in Astana on May 29, 2014) (as amended on May 8, 2015) (as amended and supplemented, effective from August 12, 2017). URL: http://www.consultant.ru/document/cons doc LAW 163855/

[7] Common markets within the Eurasian Economic Union: the movement of goods, services, labor and capital. [Obshchie rynki v ramkakh Evraziiskogo ekonomicheskogo soyuza: dvizhenie tovarov, uslug, truda i kapitala]. https://eabr.org/upload/data/EDB_Centre_2017_Monograph_Chapter_4. pdf

[8] The Eurasian Economic Union in Figures: a brief statistical compilation; The Eurasian Economic Commission [Evraziiskii ekonomicheskii soyuz $\mathrm{v}$ tsifrakh: kratkii statisticheskii sbornik; Evraziiskaya ekonomicheskaya komissiya], Moscow: 2017, p. .27.
[9] Spletukhov, Yu.A, "Insurance markets of the EEA member states: current state and efficiency" [Strakhovye rynki gosudarstv-chlenov EAES: sovremennoe sostoyanie i effektivnost' ], in Research Financial Institute. Financial Journal [Nauchno-issledovatel'skii finansovyi institut. Finansovyi zhurnal], Eds. Spletukhov Yu.A., Vol. 2 (36), 2017, pp. 105-114.

[10] Grigorenko, I.V., "Features of the requirements for the financial stability of insurance organizations in the framework of international economic integration" [Osobennosti trebovanii $\mathrm{k}$ finansovoi ustoichivosti strakhovykh organizatsii $\mathrm{v}$ ramkakh mezhdunarodnoi ekonomicheskoi integratsii], in Insurance business [Strakhovoe delo]. Eds. Grigorenko I.V., Anufrieva T.E., Vol. 9, 2017, p.10.

[11] Grigorenko, I.V., "Development of the Russian insurance market in the context of international economic integration" [Razvitie rossiiskogo strakhovogo rynka $\mathrm{v}$ usloviyakh mezhdunarodnoi ekonomicheskoi integratsii], in Alternatives for regional development [Al'ternativy regional'nogo razvitiya]: proccedings of the 8 Annual International Conference to commemorate the scientist and public figure I. P. Shabunin, Eds. Anikina I.D. et al., Volgograd, October 25-27, 2017, in 2 vols. Vol. 2., Volgograd: VolSU Publishing, 2017, pp. 6-16.

[12] Dyuzhikov, E.F., "On general approaches to regulation and the unified insurance market of the EEU" [K obshchim podkhodam $k$ regulirovaniyu $\mathrm{i}$ edinomu strakhovomu rynku EAES], in Finance [Finansy], Eds. Dyuzhikov E.F., Vol. 9, 2015, pp. 33 - 38.

[13] Grigorenko, I.V., "Conditions for the introduction of international standards for solvency regulation and control in the Russian insurance market." [Usloviya vnedreniya mezhdunarodnykh standartov regulirovaniya $\mathrm{i}$ kontrolya platezhesposobnosti na rossiiskom strakhovom rynke] in I. Grigorenko, Insurance business [Strakhovoe delo], Vol. 4 (265), 2015, p.33.

[14] Tsyganov, A.A., "Integration process in the insurance markets of the EEU countries" [Integratsionnyi protsess na strakhovykh rynkakh stran evraziiskogo ekonomicheskogo soyuza], in A.A. Tsyganov, Trends and prospects for the development of the Eurasian Economic Union in the context of the experience of European integration and global challenges [Tendentsii i perspektivy razvitiya Evraziiskogo ekonomicheskogo soyuza v kontekste opyta evropeiskoi integratsii i global'nykh vyzovov], Eds. L.N. Beauty: Proccedings of the International Scientific and Practical Conference, Moscow, April 21, 2015, Moscow: Financial University, 2016, p.148. 